
\title{
$\begin{array}{ll}\text { Research Square } & \begin{array}{l}\text { Preprints are preliminary reports that have not undergone peer review. } \\ \text { They should not be considered conclusive, used to inform clinical practice, } \\ \text { or referenced by the media as validated information. }\end{array}\end{array}$
}

\section{Autoimmune Haemolysis After Operation of Gastric Cancer Complicated With Drug-refractory Idiopathic Thrombocytopenic Purpura: a Case Report and Review of the Literature}

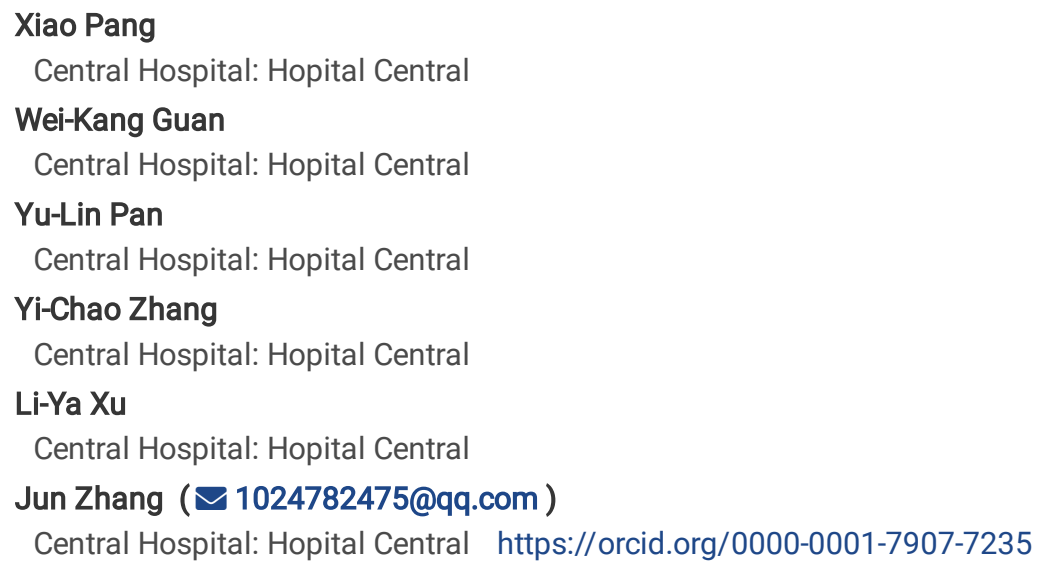

\section{Research Article}

Keywords: Gastric cancer, Idiopathic thrombocytopenic purpura, Autoimmune hemolysis

Posted Date: May 20th, 2021

DOI: https://doi.org/10.21203/rs.3.rs-537900/v1

License: (1) This work is licensed under a Creative Commons Attribution 4.0 International License. Read Full License 


\section{Abstract}

Background: To the best of our knowledge, few reports are available at home and abroad on autoimmune haemolysis occurring after operation of gastric cancer complicated with drug-refractory idiopathic thrombocytopenic purpura (ITP)(Table 1). The treatment process in this case is usually risky, and multidisciplinary collaboration is often required. Therefore, the case report aims to improve the awareness of the perioperative management of this type of patients.

Case presentation: A 69-year-old male admitted to the hospital for "anaemia" was diagnosed with gastric adenocarcinoma after gastroscopy and biopsy. This diagnosis was confirmed to be an early stage by abdominal CT imaging. However, the patient had an extremely low platelet level and a history of hormone therapy. Moreover, administration of thrombopoietin and immunoglobulin was ineffective for treatment. After transfusion of aphaeretic platelets, laparoscopic total gastrectomy with D2 lymphadenectomy and splenectomy were performed. Anastomotic bleeding and autoimmune haemolysis occurred after the operation. Haemolytic symptoms were spontaneously relieved after a period of hospitalisation.

Conclusion: This case involved many disciplines, and revealed the interaction and mutual promotion of gastric cancer, ITP and autoimmune haemolysis, but further relationships need to be further investigated.

\section{Background}

Tumours rarely combined with two types of blood diseases resulting from the failure of immune mechanism regulation. Blood diseases may combine arbitrarily and interact with each other. Here, we present a patient with drug-resistant idiopathic thrombocytopenic purpura(ITP) who experienced gastric cancer and autoimmune haemolysis.

\section{Case Presentation}

A 69-year-old male patient was admitted to the Department of Haematology because of fatigue and dizziness lasting 1 month. The patient had fatigue for 1 month, and the symptom was gradually aggravated 1 week prior to his visit. The patient was unable to carry out physical activity and had dizziness. Five years ago, the patient was hospitalised at the Department of Haematology of our hospital for treatment of thrombocytopenia and diagnosed with ITP with a platelet count of $7 \times 109 / \mathrm{L}$ on admission. After treatment with $30 \mathrm{mg}$ qd of prednisone for 3 days, the patient was voluntarily discharged from the hospital. The patient took platelet-elevating drugs irregularly after discharge and did not return to re-examination. No family history of cancer or haematological diseases. On admission, the patient's temperature was $36.6^{\circ} \mathrm{C}$, heart rate was $77 \mathrm{bpm}$, respiratory rate was 16 breaths per minute, blood pressure was 138/97 mmHg, and the physical examination revealed no positive sign. But the patient's routine blood test showed a haemoglobin level of $63 \mathrm{~g} / \mathrm{L}$, platelet count of $34 \times 109 / \mathrm{L}$, bone marrow smear indicated hypochromic microcytic anaemia, enhanced abdominal CT examination revealed stage T1-2NO cancer (Fig. 1), gastroscopy revealed $1.5 \times 1 \mathrm{~cm} 2$ necrotic foci at the posteriorwallof the lessercurvatureof the gastricbody, and apathological test confirmed adenocarcinoma (Fig. 2). The patient was finally diagnosed with gastric cancer.

The patient was transferred from the Department of Haematology to the Department of General Surgery and double-checked routine blood examination (haemoglobin level, 71 g/L; platelet count, 36×109/L). After amultidisciplinary discussion,we decided to continuously subcutaneous inject $15000 \mathrm{IU}$ of thrombopoietin (TPO) into the patient for 2 weeks. However, no satisfactory therapeutic effect was found after re-examination. Accordingly,on the sixth day,we combined intravenous immunoglobulin (IVIG; $400 \mathrm{mg} / \mathrm{kg}$ ) for 5 days. Last, laparoscopic total gastrectomy with D2 lymphadenectomy (LTG-D2) + splenectomy + Braun's anastomosis was performed after platelet transfusion. Serious abdominal adhesion was observed during the operation, and the operation time lasted 7 hours. On the first day after operation, the patient was re-examined with routine blood test and revealed a haemoglobin level of $80 \mathrm{~g} / \mathrm{L}$ and platelet count of $62 \times 109 / \mathrm{L}$. On the fifth day after operation, $200-400 \mathrm{~mL}$ of a dark red blood-like fluid was founded from the patient's nasogastric tube. We considered gastrointestinal anastomotic stoma bleeding and decieded to use somatostatin, a proton pump inhibitor, thrombin and suspended red blood cells for treatment. Bleeding of the anastomotic stomagradually decreased, but dark-brown urine was noted on the 13th day after operation. The patient was re-examined with routine blood test and revealed a white blood cell (WBC) count, haemoglobin level, and platelet count of $21.93 \times 109 / \mathrm{L}, 52 \mathrm{~g} / \mathrm{L}$ and $116 \times 109 / \mathrm{L}$, respectively. The patient's liver function was generally normal. Routine urine test showed $4+$ bilinogen and $11.9 \%$ reticulocytes. Indirect and indirect anti-human-globulin (Coomb's test) tests were negative. After remote consultation in the Department of Haematology of the West China Hospital of Sichuan University, blood transfusion-related haemolysis was excluded, considering possibilities of Coomb's test-negative autoimmune haemolysis, infection, tumour and other factors. We considered the effects of hormones and immunosuppressants on the anastomotic stoma and infection control, decided to temporary observation and adjust cefoperazone/sulbactam to imipenem/cisastatin ( $1 \mathrm{~g} \mathrm{q} 8 \mathrm{~h})$. Thereafter, the patients was regularly examined through routine blood and urine tests, and the relevant indices gradually improved. The patient was discharged on the 26 th day after operation with a WBC of $8.56 \times 109 / \mathrm{L}$, haemoglobin level of 62g/L and platelet count of 57×109/L (Fig. 3).

Page 2/8 
The patient's postoperative pathological test: stomach and lymph nodes: moderately and highly differentiated tubular adeno carcinoma invading the muscularis mucosa without lymph node metastasis (Fig. 4); spleen: congestive splenomegaly (Fig. 4). Pathological stage: T1aNOM0, stage IA. The patient was followed up 3 months and 6 months after operation and re-examined with routine blood test. A WBC count, haemoglobin level and platelet count of 5.72/6.35×109/L,92/114g/L and 44/41×109/L, respectively.

\section{Discussion}

ITP is an autoimmune disease, and its cause has yet to be identified. The pathogenesis of ITP is generally recognised to involve stimulation of the immune system by the antigenicity produced by platelet membrane proteins, thus causing destruction or reduction of platelets[1]. Drugrefractory ITP refers to PLT count $\otimes 30000 / \mu \mathrm{L}$ or increase by less than twice the baseline count after drug treatment[2]. Earlier studies suggested that splenectomy as a second-line treatment regimen may cause short-term platelet responses in approximately $87 \%$ of ITP patients[3-5]. However, because chemotherapeutic drugs could produce myelosuppression, drug-refractory ITP is an absolute contraindication of chemotherapy.Whilst we considered endoscopic submucosal dissection(ESD)for early gastric cancer, especially welldifferentiated gastric cancer of the non-ulcerative type $(<2 \mathrm{~cm})$, the problem of long-term thrombocytopenia could not be resolved. Therefore, radical gastrectomy + splenectomy is the only choice for the treatment of gastric cancer complicated with drug-refractory ITP.

Gastric cancer surgery belongs to a kind of operation within a time limit. Considering the influence of hormones and immunosuppressants on operation outcomes, IVIG combined with platelet treatment is effective in case of failure of conventional TPO treatment before operation[6]. If the need to increase the platelet count within a short period of time arises, the conventional treatment planes administration of IVIG (0.4g/ $\mathrm{kg}$ ) for 4-6 hours a day for up to 5 days. If the patients poor response to the conventional treatment and tolerance to IVIG, the infusion time of IVIG is increased. For example, an IVIG dose of $1 \mathrm{~g} / \mathrm{kg}$ with continuous infusion for 24 hours and $1 \mathrm{U}$ platelets every 8 hours[7]. Previous studies suggested that the effect of IVIG on platelets depends on the specificity of autoantibodies to platelet receptors. IVIG could increase the platelet count of GPIla-IIb receptor-specific antibodies but not that of the GPIB receptor[8, 9].

Compared with the average person, ITP patients are at greater risk of developing post-operative anastomotic stoma bleeding because of their abnormal coagulation mechanism. Thus, post-operative observation of blood pressure, heart rate, haemoglobin level and drainage and nasogastric tubes is very important. Although most cases of bleeding could be improved by conservative treatment with internal medicine[10], uncontrollable bleeding may be fatal to patients who are unable to address the issue in time. Re-operation, endoscopic haemostasis and interventional surgery are all available options for bleeding[11]. A growing number of reports have revealed that, compared with other methods, therapeutic endoscopy has more advantages in terms of reducing trauma, identifying bleeding sites and assessing rebleeding and could achieve more satisfactory results[12-15]. In addition, therapeutic endoscopy can be easily combined with other treatment methods. Umano $Y$ et al. reported that microwave therapy under endoscopy could help bleeding sites coagulate[16]. Tanizawa $Y$ and Tang SJ et al. reported the use of titanium clips for haemostasis under endoscopy[13,17]. Granata A et al. reported the use of styptic powder for haemostasis under endoscopy[18]. Several other studies on the use of adrenaline injection and heating probes to achieve haemostasis under endoscopy have also been published[14, 15].

ITP and autoimmune haemolysis are diseases caused by the failure of the autoimmune mechanismand related to tumourigenesis to a certain extent; indeed, the probability of tumourigenesis in patients with ITP and autoimmune haemolysis is 12-13 times higher than that of the normal population[19]. However, the specific mechanisms of these relations are not clear. A previous study revealed that the higher probability of tumourigenesis due to ITP and autoimmune haemolysis may be related to the production of carcinogenic substances by red blood cells, platelets or anti-red blood cells and anti-platelet autoantibodies [20]. Tumour cells could also produce antibodies that cross-react with the antigens of red blood cells, resulting in haemolysis [21].Haemolytic anaemia due to tumour-related immune haemolysis could be improved by beginning chemotherapy[22]. In the present case report, we opted to observe the patient without using targeted treatments. Interestingly, the patient's immune haemolysis disappeared spontaneously, probably because the corresponding antigens disappeared after the elimination of tumour factors.

\section{Conclusions}

We reported that one patient with gastric cancer complicated with ITP had anextremely low platelets count on admission. Finally, we chose LTG-D2 and splenectomy for gastric cancer,but anastomotic stoma bleeding and autoimmune haemolysis occurred after operation. The patient recovered and was discharged from the hospitalafter receiving active treatment. No complications were noted at the patient's 6-month follow-up. This combination of gastric cancer with drug-resistant ITP has rarely been reported at home and abroad. The relationship between cancer and haematological system diseases requires further study.

\section{Abbreviations}


CT=Computed Tomography

ITP=Idiopathic Thrombocytopenic Purpura

TPO=Thrombopoietin

IVIG=Intravenous Injection

LTG-D2=Laparoscopic Total Gastrectomy with D2 lymphadenectomy

WBC=White Blood Cell

ESD $=$ Endoscopic Submucosal Dissection

\section{Declarations}

\section{Acknowledgements}

Not applicable

\section{Author contributions}

Writing-original draft: Xiao Pang, Wei-Kang Guan.

Writing-review \& editing: Wei-Kang Guan, Yu-Lin Pan, Yi-Chao Zhang, Li-Ya Xu, Jun Zhang.

\section{Funding}

Not applicable

\section{Availability of date and materials}

All data and material are fully available without restriction.

Ethics approval and consent to participate

The study was approved by the Research Ethics Committee of Dazhou Central Hospital. Informed consent was obtained from the patient for the publication of the report.

\section{Consent for publication}

Written informed consent for publication was obtained from the participant.

\section{Competing interests}

The authors declare that they have no conflict of interest.

\section{References}

1. Shan NN, Dong LL, Zhang XM, Liu X, Li Y. Targeting autophagy as a potential therapeutic approach for immune thrombocytopenia therapy. Crit Rev Oncol Hematol. 2016;100:11-15. doi: 10.1016/j.critrevonc.2016.01.011.

2. Ozelo MC, Colella MP, de Paula EV, do Nascimento ACKV, Villaca PR,Bernardo WM. Guideline on immune thrombocytopenia in adults: Associação Brasileira de Hematologia, Hemoterapia e Terapia Celular. Project guidelines: Associação Médica Brasileira - 2018. Hematol Transfus Cell Ther. 2018; 40(1): 50-74. doi:10.1016/j.htct.2017.11.001.

3. Montalvo J, Velazquez D, Pantoja JP, Sierra M, López-KarpovitchX, Herrera MF. Laparoscopic splenectomy for primary immunethrombocytopenia: clinical outcome and prognostic factors. J Laparoendosc Adv Surg Tech A. 2014; 24: 466-470. doi: 10.1089/lap.2013.0267.

4. Qu YK, Xu J, Jiao CB, Cheng ZX, Ren SY. Long-term outcomes of laparoscopic splenectomy versus open splenectomy for idiopathic thrombocytopenic purpura. Int Surg. 2014; 99(3): 286-290. doi: 10.9738/INTSURG-D-13-00175.1.

5. Rijcken E, Mees ST, Bisping G, Krueger K, Bruewer M, SenningerN, Mennigen R. Laparoscopic splenectomy for medically refractoryimmune thrombocytopenia (ITP): a retrospective cohort study onlongtime response predicting factors based on consensus criteria. Int $J$ Surg. 
2014;12(12):1428-1433. doi: 10.1016/j.ijsu.2014.10.012.

6. Bavunoğlu I, Eşkazan AE, Ar MC, Cengiz M, Yavuzer S, Salihoğlu A, et al. Treatment of patients with immune thrombocytopenia admitted to the emergency room. Int J Hematol. 2016;104(2):216-222. doi: 10.1007/s12185-016-2003-5.

7. Spahr JE, Rodgers GM. Treatment of immune-mediated thrombocytopenia purpura with concurrent intravenous immunoglobulin and platelet transfusion: A retrospective review of 40 patients. Am J Hematol. 2008;83(2):122-125. doi: 10.1002/ajh.21060.

8. Leytin V, Mykhaylov S, Starkey AF, Allen DJ, Lau H, Ni H, et al. Intravenous immunoglobulin inhibitsanti-glycoprotein IIb-induced platelet apoptosis in a murine model of immunethrombocytopenia. Br J Haematol. 2006;133(1):78-82. doi: 10.1111/j.1365-2141.2006.05981.x.

9. Webster ML, Sayeh E, Crow M, Chen P, Nieswandt B, Freedman J, et al. Relative efficacy of intravenous immunoglobulin G in ameliorating thrombocytopenia induced by antiplatelet GPIlbllla versus GPIba antibodies. Blood. 2006;108:943-946. doi: 10.1182/blood-2005-06009761.

10. KimMC, Choi HJ, Jung GJ, Kim HH. Techniques and complications of laparoscopy-assisted distal gastrectomy (LADG) for gastric cancer. Eur J Surg Oncol. 2007;33(6):700-705. doi: 10.1016/j.ejso.2007.02.018.

11. Ki-Han Kim, Min-Chan Kim, Ghap-Joong Jung, Jin-Seok Jang, Seok-Ryeol Choi. Endoscopic treatment and riskfactors of postoperative anastomotic bleeding after gastrectomy for gastric cancer. Int J Surg. 2012;10(10):593-597. doi: 10.1016/j.ijsu.2012.09.026.

12. Mayer G, Lingenfelser T, Ell C. The role of endoscopy in early postoperative haemorrhage. Best Pract Res Clin Gastroenterol. 2004;18:799807. doi: 10.1016/j.bpg.2004.06.002.

13. Tanizawa Y, Bando E, Kawamura T, Tokunaga M, Ono H. Terashima M. Early postoperative anastomotic hemorrhage after gastrectomy for gastric cancer. Gastric Cancer. 2010;13(1):50-57. doi: 10.1007/s10120-009-0535-6.

14. Fernández-Esparrach G, Bordas JM, Pellisé M, Gimeno-García AZ, Lacy A, Delgado S, et al. Endoscopic management of early GI hemorrhage after laparoscopic gastric bypass. Gastrointest Endosc. 2008;67:552-555. 18. doi: 10.1016/j.gie.2007.10.024.

15. Jamil LH, Krause KR, Chengelis DL, Jury RP, Jackson CM, Cannon ME, et al. Endoscopic management of early upper gastrointestinal hemorrhage following laparoscopic Roux-en-Y gastric bypass. Am J Gastroenterol. 2008;103:86-91. doi: 10.1111/j.15720241.2007.01588.x.

16. Umano Y, Horiuchi T, Inoue M, Shono Y, Oku Y, Tanishima H, et al. Endoscopic microwave coagulation therapy of postoperative hemorrhage from a stapled anastomosis. Hepatogastroenterology. 2005;52:1768-1770.

17. Tang SJ, Rivas H, Tang L, Lara LF, Sreenarasimhaiah J, Rockey DC. Endoscopic hemostasis using endoclip in early gastrointestinal hemorrhage after gastric bypass surgery. Obes Surg. 2007; 17:1261-1267. doi: 10.1007/s11695-007-9206-z.

18. Granata A, Ligresti D, Curcio G, Barresi L, Tarantino I, Orlando R, et al. Hemospray rescue treatment of gastroenteric anastomotic bleeding.Endoscopy. 2015;47 Suppl 1 UCTN:E327-E328. doi: 10.1055/s-0034-1392322.

19. Sokol RJ, Booker DJ, Stamps R. Erythrocyte autoantibodies, autoimmune haemolysis, and carcinoma. J Clin Pathol. 1994; 47(4): 340343. doi: 10.1136/jcp.47.4.340.

20. Wakata N, Kiyozuka T, Konno S, Nazazora H, Nomoto N, Sugimoto H, et al. Autoimmune thrombocytopenic purpura,autoimmune hemolytic anemia and gastric cancer appeared in a patient with myasthenia gravis. Intern Med. 2006; 45: 479-481. doi: 10.2169/internalmedicine.45.1496.

21. Puthenparambil J, Lechner K, Kornek G. Autoimmune hemolytic anemia as a paraneoplastic phenomenon in solid tumors: A critical analysis of 52 cases reported in the literature. Wien Klin Wochenschr. 2010;122(7-8):229-236. doi: 10.1007/s00508-010-1319-z.

22. Agrawal K, Alfonso F. A Rare Association of Autoimmune Hemolytic Anemia with Gastric Adenocarcinoma. Case Rep Oncol Med. 2017; 2017: 8414602. doi: 10.1155/2017/8414602.

23. Bachmeyer C, Audouin J, Bouillot JL, Coutarel P, Mougeot-Martin M, Delmer A. Immune thrombocytopenic purpura as the presenting feature of gastric MALT Iymphoma. Am J Gastroenterol. 2000; 95: 1599-1600. doi: 10.1111/j.1572-0241.2000.02113.x.

24. Noda M, Mori N, Nomura K, Kojima K, Mitsufuji S, Yamane I, et al. Regression of idiopathic thrombocytopenic purpura after endoscopic mucosal resection of gastric mucosa associated lymphoid tissue lymphoma. Gut. 2004; 53: 1698-1700. doi: 10.1136/gut.2003.033555.

25. Villias C, Gourgiotis S, Veloudis G. Synchronous early gastric cancer and gastrointestinal stromal tumor in the stomach of a patient with idiopathic thrombocytopenic purpura. J Dig Dis. 2008; 9: 104-107. doi: 10.1111/j.1751-2980.2008.00330.x.

26. Hamabe A, Omori T, Oyama T, Akamatsu H, Yoshidome K, Tori M, et al. A case of Helicobacter pylori infection complicated with gastric cancer,gastric mucosa-associated lymphoid tissue lymphoma, and idiopathic thrombocytopenic purpura successfully treated withlaparoscopy-assisted total gastrectomy and splenectomy. AsianJ Endosc Surg. 2011; 4: 32-35. doi: 10.1111/j.17585910.2010.00067.x. 
27. Tang M, Goldsteinl. The role of chemotherapy in gastric cancer-related microangiopathic haemolytic anaemia. $J$ Gastrointest Oncol. 2017;8(1):E10-E15. doi: 10.21037/jgo.2016.11.14.

28. Seo HS, Yung YJ, Park CH, Song KY, Jung ES. IgG4-related Disease in the Stomach which Was Confused with Gastrointestinal Stromal Tumor (GIST): Two Case Reports and Review of the Literature. J Gastric Cancer. 2018;18(1):99-107. doi: 10.5230/jgc.2018.18.e8.

29. Zhao ZW, Kang WM, Ma ZQ, Ye X, Yu JC. Gastric cancer with severe immune thrombocytopenia: A case report. World J Clin Cases. 2018;6(15):1024-1028. doi: 10.12998/wjcc.v6.i15.1024.

\section{Table}

Table 1

Cases of gastric tumor patients suffer with ITP or autoimmune hemolysis.

\begin{tabular}{|c|c|c|c|c|c|c|}
\hline Ref. & $\begin{array}{l}\text { Lowest } \\
\text { number of } \\
\text { platelets(/ul) }\end{array}$ & Therapy for ITP & Type of gastric tumor & $\begin{array}{l}\text { Treatmengt } \\
\text { for gastric } \\
\text { tumor }\end{array}$ & $\begin{array}{l}\text { Therapy for } \\
\text { hemolysis }\end{array}$ & $\begin{array}{l}\text { Prognosis } \\
\text { of gastric } \\
\text { turmor }\end{array}$ \\
\hline $\begin{array}{l}\text { Bachmeyer,et } \\
\text { al,2000[23] }\end{array}$ & 40000 & $\begin{array}{l}\text { Splenectomy and } \\
\text { iv immunoglobulin }\end{array}$ & Gastric MALT Iymphoma & $\begin{array}{l}\text { Chemotherapy } \\
\text { (CHOP } \\
\text { regimens) }\end{array}$ & / & / \\
\hline $\begin{array}{l}\text { Noda M,et } \\
\text { al,2004[24] }\end{array}$ & 27000 & / & Gastric MALT Iymphoma & EMR & / & $\begin{array}{l}\text { Without } \\
\text { recurrence } \\
\text { in } 2 \text { years }\end{array}$ \\
\hline $\begin{array}{l}\text { Wakata } \\
\text { Nobuo,et } \\
\text { al,2006[20] }\end{array}$ & 1000 & $\begin{array}{l}\text { Iv immunoglobulin, } \\
\text { methylprednisolone, } \\
\text { platelet transfusion } \\
\text { and splenectomy }\end{array}$ & $\begin{array}{l}\text { Gastric } \\
\text { adenocarcinoma(Contains } \\
\text { signet ring cells) }\end{array}$ & $\begin{array}{l}\text { Subtotal } \\
\text { gastrectomy }\end{array}$ & $\begin{array}{l}\text { High doses of } \\
\text { immunoglobulin }\end{array}$ & $\begin{array}{l}\text { Without } \\
\text { recurrence } \\
\text { in } 2 \text { years }\end{array}$ \\
\hline $\begin{array}{l}\text { Villias } \\
\text { Constantionos,et } \\
\text { al,2008[25] }\end{array}$ & 76000 & Splenectomy & GIST & $\begin{array}{l}\text { Subtotal } \\
\text { gastrectomy } \\
\text { and RouX-en-Y } \\
\text { anastomosis }\end{array}$ & / & / \\
\hline $\begin{array}{l}\text { Hamabe A,et } \\
\text { al,2011[26] }\end{array}$ & 52000 & $\begin{array}{l}\text { Eradicate } \\
\text { helicobacter } \\
\text { pylori,iv } \\
\text { immunoglobulin } \\
\text { and splenectomy }\end{array}$ & Gastric MALT Iymphoma & $\begin{array}{l}\text { Total } \\
\text { gastrectomy } \\
\text { and Roux-en-Y } \\
\text { anastomosis }\end{array}$ & / & $\begin{array}{l}\text { Without } \\
\text { recurrence } \\
\text { in } 2 \text { years }\end{array}$ \\
\hline $\begin{array}{l}\text { Monica Tang,et } \\
\text { al,2017[27] }\end{array}$ & 20000 & Platelet transfusion & / & chemotherapy & $\begin{array}{l}\text { Plasma } \\
\text { exchange and } \\
\text { prednisone }\end{array}$ & / \\
\hline $\begin{array}{l}\text { Seo HS,et } \\
\text { al,2018[28] }\end{array}$ & 32000 & Oral steroid & Gastric cancer & $\begin{array}{l}\text { Subtotal } \\
\text { gastrectomy }\end{array}$ & / & $\begin{array}{l}\text { Stomach } \\
\text { wall lgG4- } \\
\text { related } \\
\text { disease } \\
\text { nine years } \\
\text { later }\end{array}$ \\
\hline $\begin{array}{l}\text { Zhao zhewei,et } \\
\text { al,2018[29] }\end{array}$ & 1000 & $\begin{array}{l}\text { Platelet transfusion } \\
\text { and splenectomy }\end{array}$ & Gastric adenocarcinoma & $\begin{array}{l}\text { Subtotal } \\
\text { gastrectomy } \\
\text { and RouX-en-Y } \\
\text { anastomosis }\end{array}$ & / & / \\
\hline
\end{tabular}

\section{Figures}



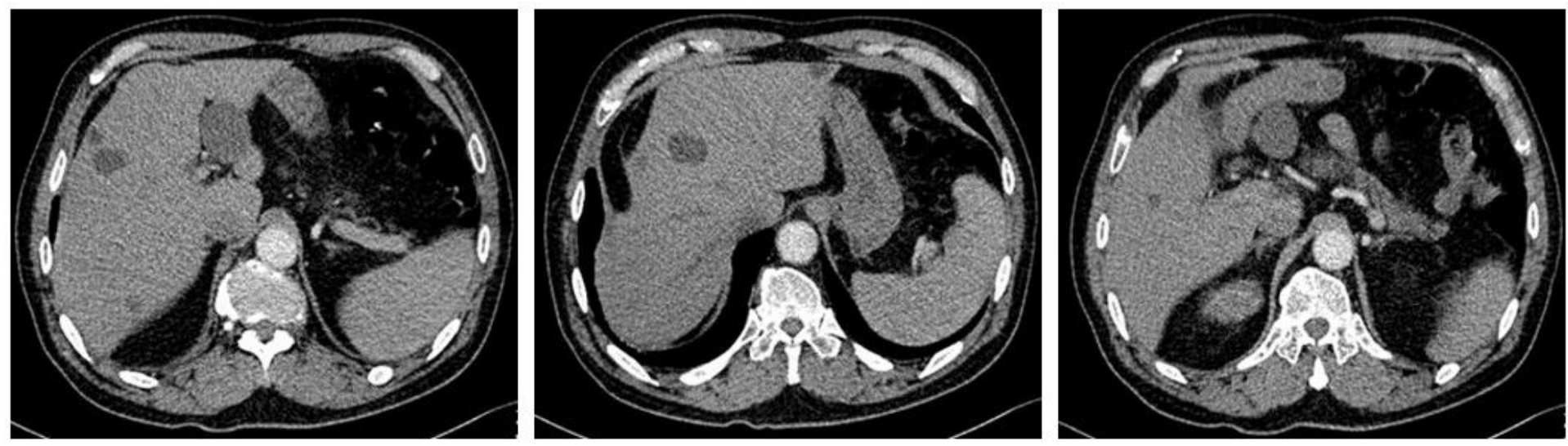

Figure 1

CT images show gastric tumors.
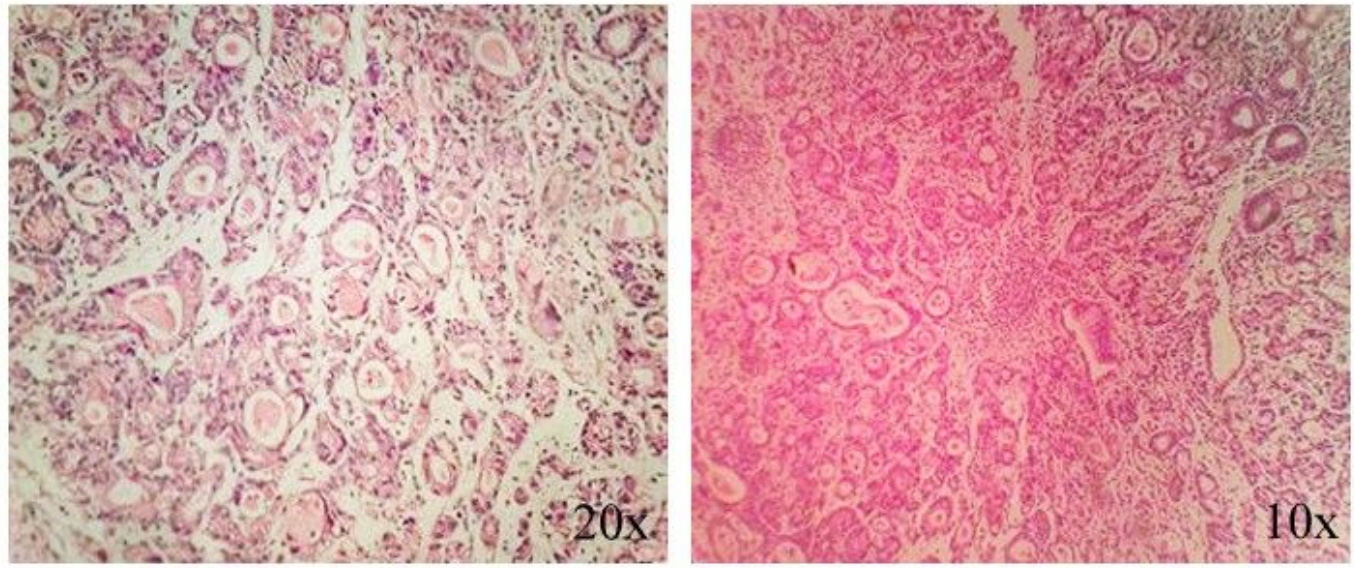

Figure 2

Pathological findings of endoscopic biopsy at high and low magnification: adenocarcinoma.

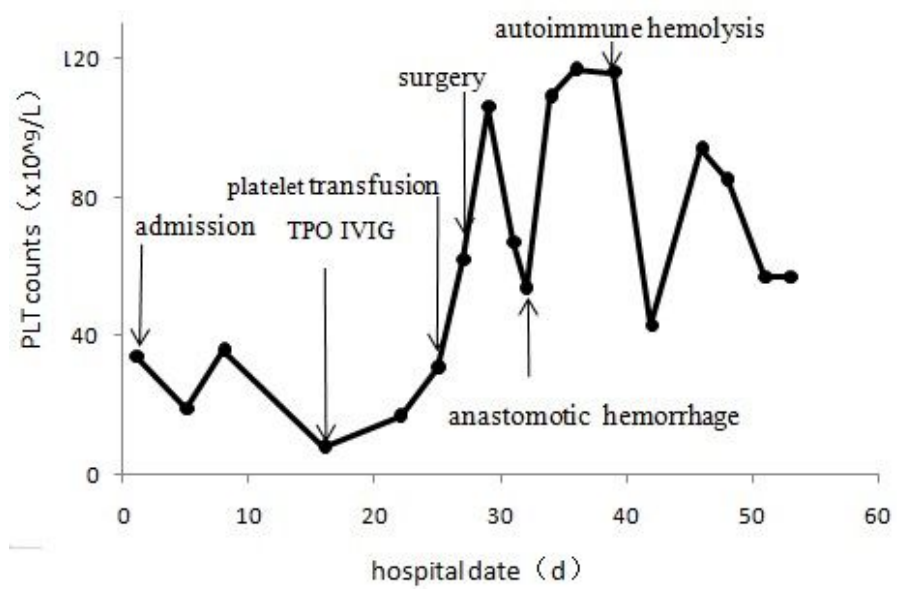

Figure 3

Platelet count fluctuation of the patient during hospitalization. 

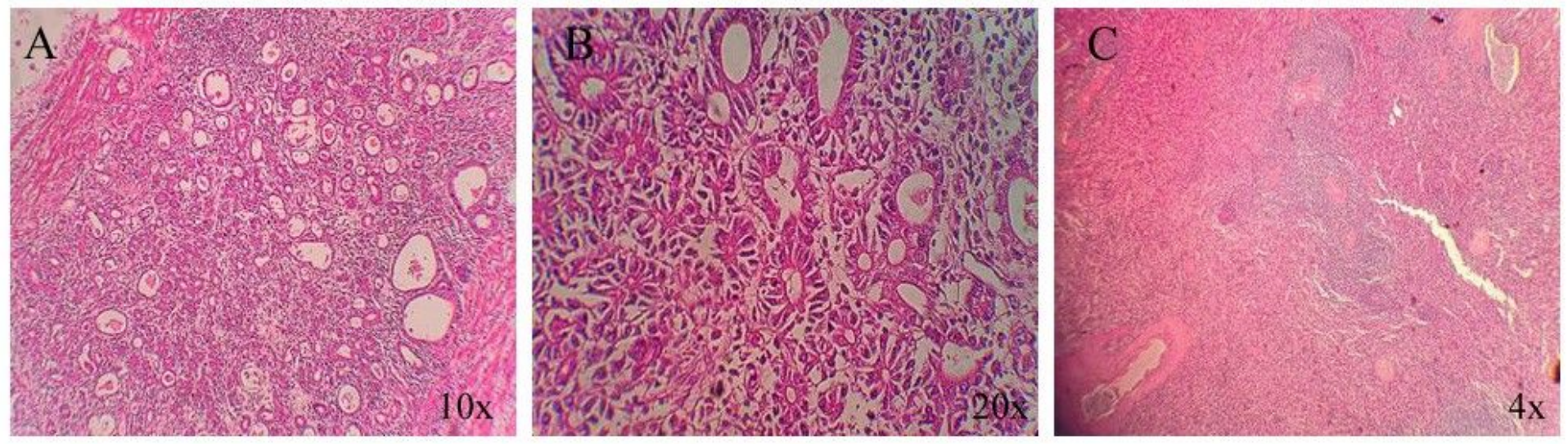

\section{Figure 4}

A showed that the tumor invaded the mucosa. B shows that at high magnification, a well differentiated glandular structure was seen. C shows the congestive splenomegaly. 